\title{
A short note on place-names in Surtsey
}

\author{
BIRNA LÁRUSDÓTTIR \\ The Árni Magnússon Institute for Icelandic studies, Laugavegur 13, 101 Reykjavík, Iceland \\ (birna.larusdottir@arnastofnun.is / birnalar@gmail.com)
}

\section{INTRODUCTION}

In the summer of 2019 the author joined a field team of biologists on Surtsey with the aim of conducting a survey of place-names on the island. This was the first comprehensive survey of this kind on Surtsey. ${ }^{1}$

From the beginning, Surtsey has been the focus of nature-driven perspectives as a scientific oasis for geological, biological and ecological research, a place to study the formation of a new landmass, erosion and the colonization and progress of flora and fauna. One species has been more or less left out on purpose in this process, namely humans. The island nevertheless offers a rare opportunity to study interactions between man and nature and human aspects of colonization and place-making processes from the beginning of the island's existence. The act of naming can be seen as an important indicator of these processes.

Often the study of place-names involves interpreting old names which may have lost their original context, appearance or meaning. Surtsey offers the rare opportunity to investigate an assemblage of names from the beginning of its history: the processes by which names appeared as people set foot on the island and started to make the landscape familiar through using names can be identified, as well as the motivations behind them and how and why some of them survive while others have already disappeared.

\footnotetext{
${ }^{1}$ This study is a part of an ongoing Phd-project carried out by the author at the University of Iceland, Faculty of Life- and Environmental Sciences.
}

\section{HISTORY AND METHODS}

In general, place-names are seen as an important part of a nation's heritage and as vital sources about the past. They are often been referred to as such, for example by historians and archaeologists as they can contain information (although sometimes fragmented) about bygone landscapes, landuse patterns, settlement history and environmental change, to name a few examples.

Conventional place-name research has been criticized for relying excessively on ,the collection and description of data (see e.g. Alderman 2008, 198), ignoring the social processes behind them" and even for being one of the driest specialist branches of linguistics (Levinson 2008, 256). However, recent advances in the field, especially within cultural geography, have brought to light the more problematic and political sides of place-names and naming processes. Much of this new research has focused on how government elites have manipulated placenames to strengthen national identity - sometimes undermining indigenous histories. Scholars have started to view landscapes as "documents of power", rather than as mere reflections of culture (Alderman 2008, pp. 196-198). Thus space (seen as a socially produced phenomenon) is viewed as a medium rather than a container for action (Tilley 1998, p. 10). This relates directly to the act of naming, as ,names act so as to transform the sheerly physical and geographical into something that is historically and socially experienced... . In a fundamental way names create landscapes." (Tilley 1998, 18-19)

The aim of this project is to investigate the dynamics of place-names and how people inscribe 
meaning, claim and connect to the landscape by naming and using names. Surtsey was seen as an ideal place to carry out this kind of research and a fascinating case study for many reasons, not least that the biographies of individual place-names would most likely be known due to the young age of the new land. Conducting a field survey was seen as fundamental to the project, which is inspired both by ethnological approaches and phenomenology. The plan was to analyse names through discussion and observing the daily routines of people familiar to the place, as well as to directly experience the landscape through fieldwalking in different circumstances to discover its many layers of meaning.

\section{BACKGROUND}

\section{The name Surtsey}

The naming of Surtsey itself was quite a famous process that was much debated in Iceland soon after the initial creation of the island in 1963. The debate has been interpreted as a manifestation of territorial disputes between locals of the Vestmannaeyjar Islands and academics in Reykjavík who represented the State (Lárusdóttir 2017). Much of the discourse took place in the media in the days and weeks following the start of the eruption. Several names for the new land were suggested by journalists, readers, local people in the Vestmannaeyjar Islands or by scientists. These names included Nýey (New Island), Gosey (Volcanic Island), Ólafsey (Ólaf's Island) after the man who first spotted the eruption, and Bjarnaey (Bjarni's Island) after the new Prime Minister of Iceland at the time, Bjarni Benediktsson. Frakkey (French Island) was also mentioned (most likely as a joke) after three French journalists from the newspaper Le Paris Match surreptitiously landed on the still erupting island before any locals had. This was not well received in the Vestmannaeyjar Islands.

On the $10^{\text {th }}$ of December 1963 the Ministry of Education announced the official name of the island, Surtsey, after having consulted the Icelandic placename committee (Örnefnanefnd) that was made up of prominent academics. The new name referred to the giant Surtur who was in charge of fire according to the famous medieval Icelandic poem Völuspá, which describes the creation (and the end) of the world. This decision about the new name caused an uproar in the Vestmannaeyjar Islands. It even led to a nearly fatal boat trip taken by some locals to the site of eruption a few days later with the aim of erecting a

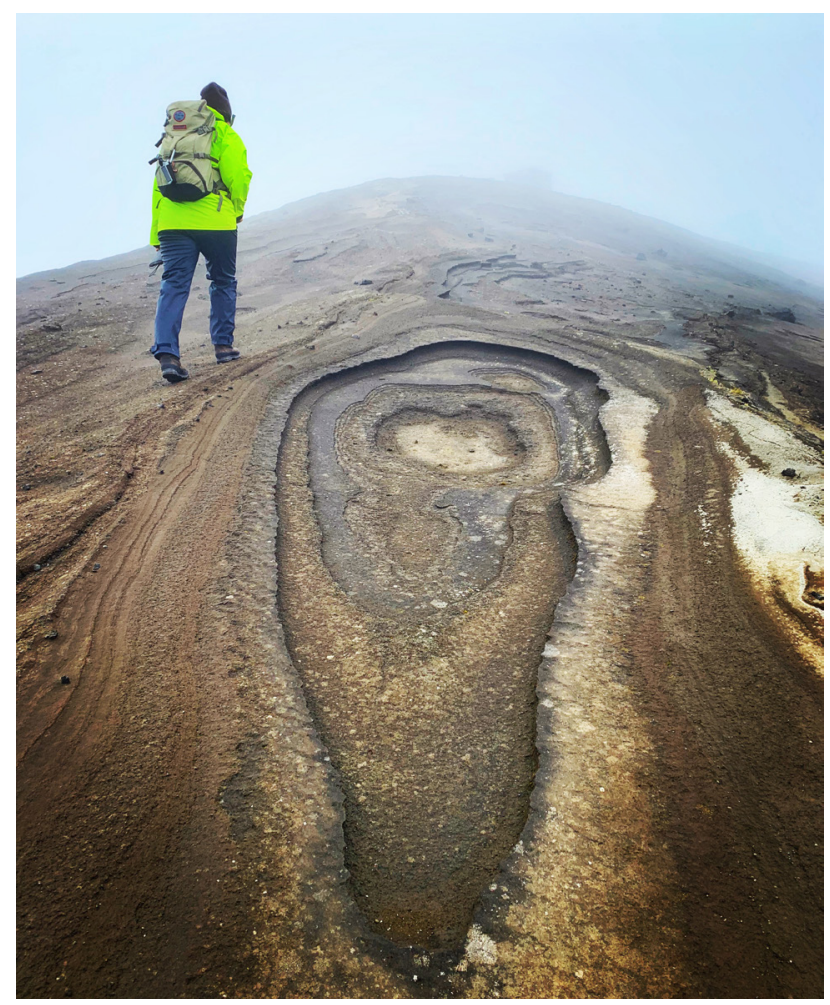

Figure 1. Póra Pétursdóttir hiking up Austurbunki on her way to the lighthouse.

home-made sign with their preferred name, Vesturey (West Island), referring to its geographical location as a part of the bigger cluster of islands. Despite their efforts, the name Surtsey stuck. Knowledge of this highly political naming process was an important prelude to the forthcoming fieldtrip to Surtsey.

\section{PREPARATION}

\section{Maps and written sources}

In preparation, all known names were collected from some key sources. A total of around 40 names were collected before the journey. Some seemed well established and appeared repeatedly, i.e. the name of the crater Surtur; the two prominent hills around the craters, Austur- (Fig. 1) and Vesturbunki; and Svartagil, a gully leading up from the old Pálsbær location up between the craters. Pálsbcer, the cabin built in the 1960s and named in honour of scientist Paul Bauer whose donation made the building possible, was also mentioned in many sources. Later, the hut was threatened by erosion, moved to a new location and named Pálsbcer II (Fig. 2). More places were named after the legendary Paul, e.g. Pálstindur, the name of the highest peak of the island and Bóndi (farmer), an Icelandic translation of his last name Bauer. Neither name is in use today. 


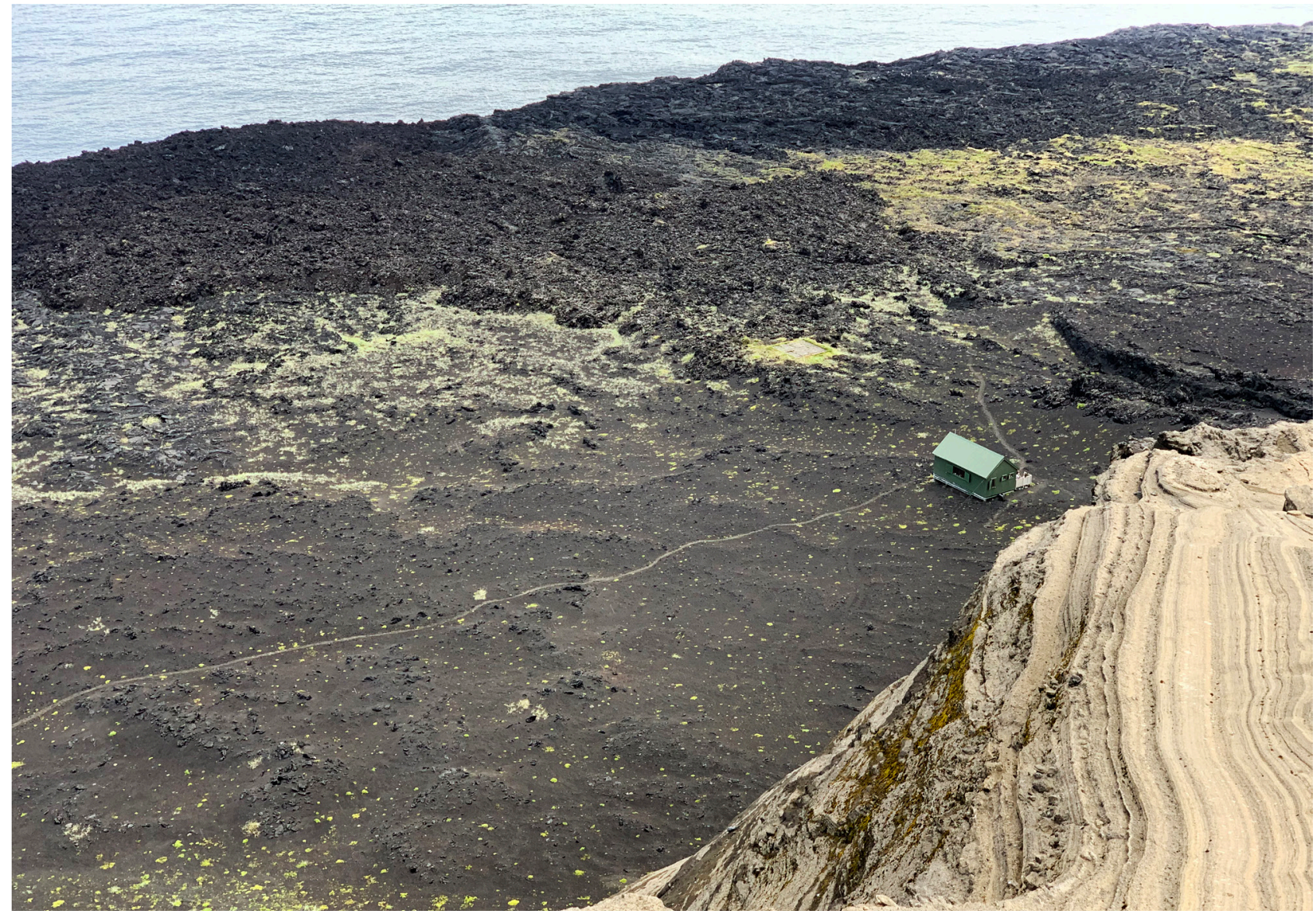

Figure 2. A view over Pálsbær. Paths appeared after a few days, marking the most commonly walked routes of visitors.

One of the newest maps of Surtsey and a key source shows a total of 21 names, including names in the northern part of the island of features which now have disappeared (Ólafsson \& Ásbjörnsdóttir 2014 , p. 13). What is unusual about this map is that the authors distinguish between established and unestablished names. This raises some questions about the basic nature of names. When does a reference to a place in fact become a placename and what elements does it need to include in order for it to be accepted on a map? What was the difference between established names and the other references? Were the names perhaps seen as being on different levels in the place-naming process?

Some features seemed to have more than one name, perhaps because different groups of people referred to them differently. New names seemed to have been added over time, perhaps by new scientists or because the island was evolving -whether due to erosion or the expanding vegetation. There were also examples of names which appeared early on but fell out of use. It

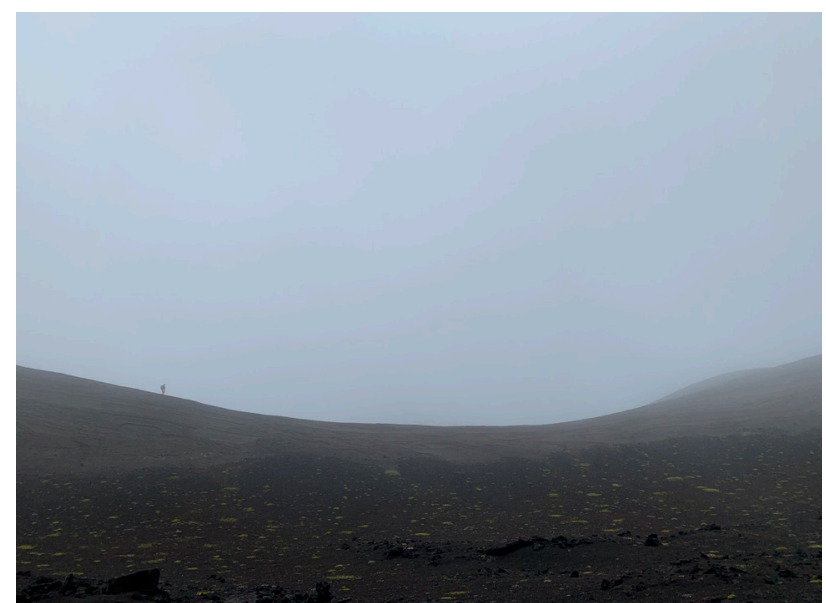

Figure 3. A human figure just visible in the fog north of the crater Surtungur.

should be noted that the maps and other sources cannot be seen as giving complete overviews of existing place-names at certain points in time but rather as indicators for them. It was hoped that the field trip would answer some questions and fill in some gaps. 


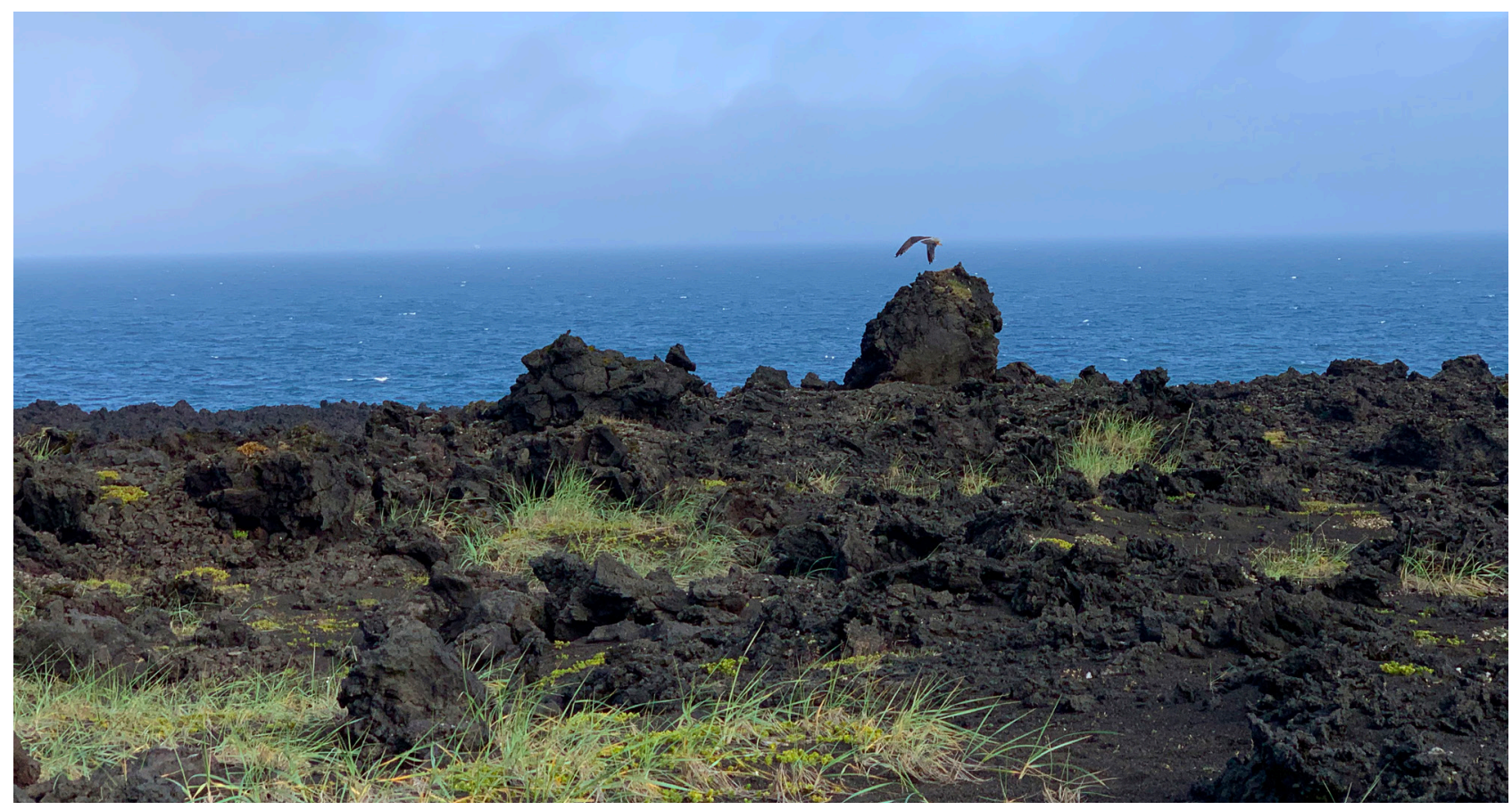

Figure 4. Mávasteinn („Seagull Rock”) is visible from the cabin Pálsbær

\section{THE SURVEY}

The trip to Surtsey was a very meaningful experience and it provided invaluable insights into the naming process on Surtsey and beyond: what motivates and affects the giving of names, how names are used and how meaning is created in landscapes. Despite foggy - even mystical - conditions during the first two days (Figs. 1 and 3), the island slowly emerged and materialized through the visible features, histories and names of places. A total of around 80 names has now been collected. The data are still being processed and theorized and will have to await further discussion and analysis although a few notes are given below.

Even if Surtsey has never been permanently settled in the conventional sense, many names indicate a certain process of place-making which relates noticeably to perspectives from dwellings, routes between key areas, and permanent research plots defined by biologists to monitor the development of life. Examples include Svartagil, a gully between the two hills which was the main route between the old Pálsbcer cabin and the craters; and Rauðabrik, an informal name for one of the smaller craters that derives from the red colour of one of the crater sides most visible from the area now referred to as máfabyggðin (the seagull colony), where scientists often conduct their research. Research plots are usually identified by numbers $(10,12)$ but there are

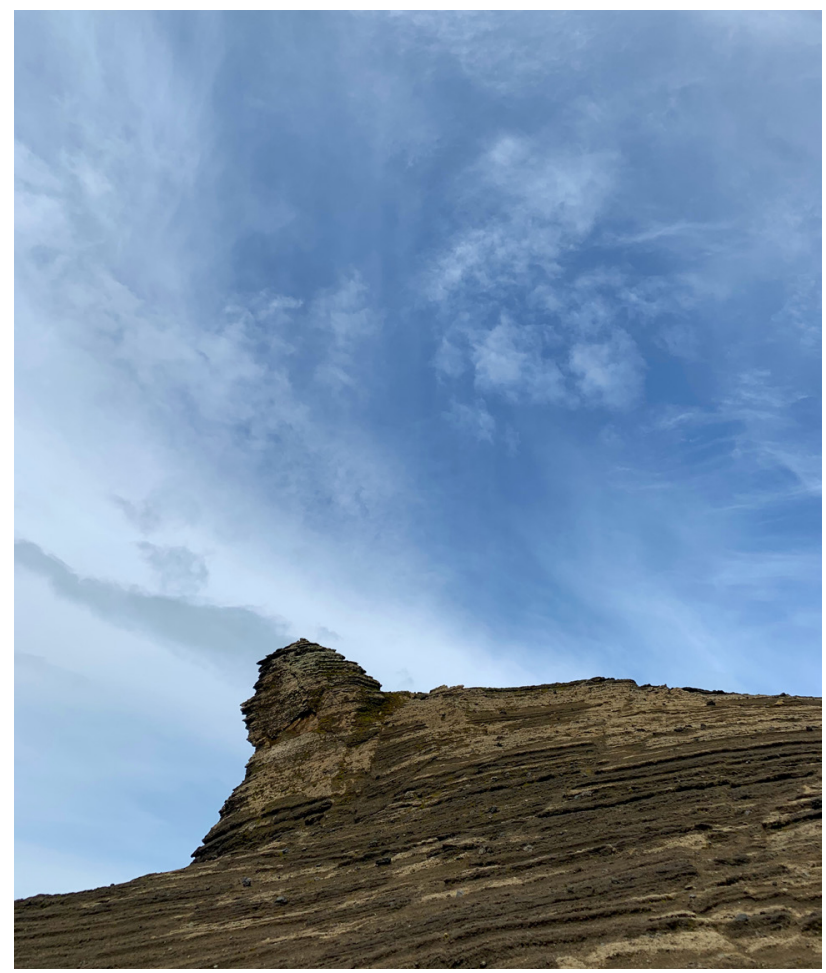

Figure 5. This cliff is often referred to as Sfinxinn („The Sphinx”) for obvious reasons although some other naming suggestions have been discussed.

some examples of those references behaving like names (e.g. Tían), and this shows an interesting combination of two different reference systems. 
Scales of names are very different: thus, there are names for very prominent landscape features that can be viewed from a long distance (Figs. 4 and 5). Other examples are e.g. Austur- and Vesturbunki, which interestingly seem to relate to similar craterhills also called bunkar in other small islands near by); and there are also names for small patches which have originally been defined by a plant species (e.g. Muruhóll and Hvanndalur).

Some earlier names are not in use anymore (e.g. Mávaból and Pálstindur); some places were referred to as if they had names but my travel companions nevertheless did not perceive them as such (e.g. tanginn, ,the spit'-, and vitinn, ,the lighthouse'). There were also examples of names that had been contemplated and discussed at some point but dismissed for various reasons. Some names obviously had a humorous element, e.g. a new name relating to the very primitive toilet facilities under a cliff on the east coast of the island called Gústavsberg, which is a well known manufacturer of toilets and sinks. Furthermore, there were examples of landscape features which have now disappeared on account of the dramatic landscape change on the island - but somehow, these places live on through the names, e.g. Fjallið eina and Bólfell.

The complexity of the data underlines how names connect to the everchanging nature of the landscape and the angle of the viewer - and how place-names encapsulate the fascinating network of natural/human relations.

\section{ACKNOWLEDGEMENTS}

I sincerely thank the Surtsey society for permitting fieldwork undertaken on the island. I am also most grateful to the field team: Bjarni Diðrik Sigurðsson, Borgpór Magnússon, Erling Ólafsson, Matthías Alfreðsson and Pawel Wasowicz were all extremely friendly and generous in passing on their knowledge of place-names and the legacy of earlier scientists in Surtsey. I also want to express gratitude to my colleague Póra Pétursdóttir at the University of Oslo and another Surtsey-enthusiast, for many inspiring conversations during our time in Surtsey. Emily Lethbridge read a draft of this short paper, detected some errors and gave some very useful comments.

This study is supported thanks to a research position linked to the name of Sigurour Nordal at the Árni Magnússon Institute for Icelandic studies, Reykjavík.

\section{REFERENCES}

Alderman, D. H., 2008. Place, Naming and the Interpretation of Cultural Landscapes. In Graham, B. and P. Howard (eds), The Ashgate Research Companion to Heritage and Identity, Farnham: Ashgate, pp. 195-213.

Lárusdóttir, B., 2017. Аð nema land með nafni. Skírnir 191 (spring), 166-185.

Levinson, S. C., 2008. Landscape, seascape and the ontoology of places on Rossel Island, Papua New Guinea. Language Sciences 30, 256-290.

Ólafsson E. \& L. Ásbjörnsdóttir, 2014. Surtsey í sjónmáli. Edda útgáfa.

Tilley, C., 1994. A Phenomenology of Landscape. Places, Paths and Monuments. Oxford: Berg. 